\title{
Ekranisasi Alur Cerita pada Novel Jinnlíng Shísān Chāi)《金陵十三 钗》Karya Yán Gē Líng ke Film The Flower of War (Sebuah Kajian Alih Wahana)
}

\author{
Intan Erwani/Hesti \\ Program Studi S1 Sastra Cina-FIB Universitas Sumatera Utara, Medan-Indonesia \\ Email: intanerwany@gmail.com
}

\begin{abstract}
ABSTRAK
Penelitian ini bertujuan mendeskripsikan proses ekranisasi pada alur cerita dalam novel Jinlíng Shísān Chāi 《金陵十三钗》 karya Yan Ge Ling yang digambarkan ke film The Flower of War. Peneliti memilih topik ekranisasi alur cerita pada novel 《金陵十三钗》ke film The Flower of War karena kedua karya tersebut berhasil mendapat penghargaan. Metode yang digunakan dalam penelitian ini adalah metode deskriptif kualitatif. Dengan menggunakan teori ekranisasi dan teori alur Robert Stanton, penelitian menganalisis alih wahana pada alur cerita novel ke film. Hasil penelitian ini adalah terdapat penambahan, pengurangan/penciutan yang terjadi pada alur cerita pada novel 《金陵十三钗》ke film The Flower of War sebagai akibat dari proses ekranisasi.
\end{abstract}

Kata kunci: Jīnlíng Shísān Chāi, The Flower of War, Yang Ge Ling, Ekranisasi, alur

\section{A. Pendahuluan}

Kusasteraan China sudah ada sejak zaman prasejarah tepatnya sejak Dinasti Xia (夏) (abad 2100-1600SM) dan Dinasti Shang (商) (abad 1700-1222SM). Xun (1925: 4) mengatakan bahwa novel adalah salah satu jenis karya sastra Cina yang sudah ada sejak Dinasti Han(206-220 SM). Meskipun pada awalnya hanya berupa kumpulan-kumpulan cerita yang dijilid kedalam sebuah buku, kumpulan itu merupakan bentuk novel yang paling awal. Ia juga menambahkan bahwa banyak sejarahwan beranggapan novel Cina bermula dari mitos karena berasal dari pengamatan suku primitif mengenai fenomena-fenomena alam seperti angin, hujan, gempa bumi, dan lain lain.

Selanjutnya, pada masa enam Dinasti, yaitu Dinasti Tang (618-907), dan Dinasti Song (960-1279), novel masih kurang populer dibandingkan dengan karya sastra lainnya, seperti Shi Ge (诗歌), Lu Shi(律诗), dan Ci (词). Xiang dan Yu ( 2012 :153) mengatakan bahwa setelah Dinasti Song digantikan oleh Dinasti Yuan (1271-1386) ditemukan jenis karya sastra yang ditulis dengan dialek penduduk setempat tertentu, penggunaan bahasa seperti ini banyak ditemukan pada novelnovel populer, seperti Shui Hu Zhuan《水汻传》, Xi You Ji《西游记》dan lain sebagainya. 
Mereka juga menambahkan bahwa semenjak Dinasti Yuan berdiri, karya sastra China yang semula memiliki tema mengutarakan isi hati pengarang berganti menjadi tema yang bersifat fiksi naratif.

Novel terus berkembang selama Dinasti Ming (1368-1644) dan Dinasti Qing (1644-1911), sehingga dihasilkan pula 4 novel klasik yang terkenal pada masa 3 dinasti ini yaitu : San Guo Yan Yi 《三国演义》, Shui Hu Zhuan《水湤传》, Xi You Ji 《西游记》dan Hong Lou Meng《红 楼梦》. Selain itu, banyak Novel Cina yang terinspirasi dari kisah nyata contohnya: novel The Last Empress karya Anchee Min terinspirasi dari biografi ibu suri Ci Xi pada Dinasti Qing, dan novel Three Inch Golden Lotus: A Novel on Foot Binding karya Feng Ji Cai yang terinspirasi dari tradisi mengikat kaki anak perempuan di Cina, dan sebagainya.

Novel 《金陵十三钗》 (Jinnling shisān chäi) merupakan novel yang ditulis oleh Yan Ge Ling dan diterbitkan pertama kali pada tahun 2005 dalam bentuk novel pendek atau novella. Novel yang ditulis oleh Yan tersebut terinspirasi dari diari seorang misionaris Amerika bernama Minnie Vautrin yang ditulis pada masa invasi Jepang ke kota Nanking pada 1937.

Novel ini berkisah tentang sekelompok murid sekolah Katolik yang bersembunyi di Gereja Wilson saat Jepang menginvasi kota Nanking. Selama peristiwa ini, persediaan makanan dan minuman semakin menipis serta ditambah pula kedatangan tiga belas wanita penghibur untuk berlindung di gereja Wilson dan tiga orang prajurit China yang terluka membuat pendeta Ingelmann dan Fabio harus mengambil keputusan yang tepat untuk melindungi para pengungsi ini.

Novel 《金陵十三钗》(Jinnlíng shisān chāi) memeroleh penghargaan orisinalitas majalah bulanan pada acara penghargaan Bai Hua Jiang ke-12 tahun 2006 serta menerima penghargaan novel terbaik dari kumpulan novela pada tahun yang sama. Yan, kemudian, menerbitkan novel 《金陵十三钗》 (Jīnlíng shísān chāi) versi panjang pada tahun 2012.

Film The Flowers of War merupakan hasil alih wahana dari novel 《金陵十三钗》 (Jìnlíng Shísān Chāi) dan dirilis pada tahun 2011 merupakan film arahan sutradara terkenal China, Zhang Yi Mou. Film ini menghabiskan dana hingga 94 juta dollar Amerika dan berhasil meraih nominasi dalam 84th Academy Awards, 69th Golden Globe Awards, dan 6th Asian Film Awards. Berdasarkan prestasi yang diraih tersebut memperlihatkan bahwa film The Flowers of War layak untuk dikaji.

Alih wahana karya sastra telah menjadi bagian yang penting dalam film Cina tahun1920an dikarenakan pasaran film di Cina pada masa itu didominasi oleh film Barat sekitar 10\% dari 500 
film yang diputar buatan Cina, sehingga membuat para sutradara Cina berusaha mengikuti perkembangan tren salah satunya dengan cara mengalihwahanakan karya sastra menjadi sebuah film (Thompson \& Bordwell, 2003 :249). Jenis karya sastra yang dialihwahanakan yaitu literatur klasik karya penulis kontemporer Cina, drama Shakespeare sampai novel Tolstoy. Karena bersumber dari teks, film hasil alih wahana sering menjadi sarana yang praktis untuk ditujukan kepada masyarakat lluas mengenai budaya, sejarah, dan politik (Qin, 2007: 2).

Damono sebagaimana dikutip oleh Widyastuti (2012: 3) mengatakan bahwa alih wahana adalah perubahan dari satu jenis kesenian ke jenis kesenian lain. Karya sastra tidak hanya bisa diterjemahkan, dengan kata lain dialihkan dari satu bahasa ke bahasa lain, tetapi juga dapat dialihwahanakan, yakni diubah menjadi kesenian lain. Misalnya seperti cerita rekaan dapat diubah menjadi tari, drama, atau film, sedangkan puisi juga bisa diubah menjadi lagu dan lukisan. Hal ini sebaliknya dapat juga terjadi, yakni novel ditulis berdasarkan film atau drama, sedangkan puisi dapat lahir dari lukisan atau lagu.

Perbandingan antara sastra dan film, atau studi ahli wahana yang menyangkut sastra dan film, pasti akan sampai pada kesimpulan bahwa keduanya berbeda sebab memang merupakan dua benda budaya yang berbeda hakikatnya (Damono, 2012: 105). Pendapat ini ditentang oleh Boyum yang berpendapat bahwa film dapat dikatakan merupakan wujud evolusi natural dari sastra (Qin, 2007: 5)

Dalam kehidupan sehari-hari sering ditemukan pernyataan yang mengungkapkan kemarahan atau kekecewaan karena film yang dibuat berdasarkan novel tidak setia kepada sumbernya. Ada adegan yang dipotong, ada yang diubah, ada juga bagian yang digeser, dan bahkan ada film yang menambah cerita yang tidak terdapat pada novel. Tidak jarang, film yang menghilangkan tokoh pada novel asli, bahkan ada juga yang memunculkan tokoh yang tidak ada dalam novel.

Dalam kenyataan ada film bagus yang didasarkan pada novel yang nilainya tidak setinggi dipandang dari segi sastra, tetapi ada juga film yang mutunya dianggap rendah meskipun bahannya adalah karya sastra bermutu. Berdasarkan sejumlah penghargaan dan tanggapan positif yang berhasil diraih oleh Film The Flowers of War yang merupakan hasil alih wahana dari novel 《金 陵十三钗》 (Jinlíng shísān chāi), peneliti tertarik untuk mengkaji prose ekranisasi yang fokus pada alur cerita novel 《金陵十三钗》(Jīnling shísān chāi) karya 严歌苓 (Yan Ge Ling) ke film The Flower of War. Dengan demikian, rumusan masalah penelitian ini adalah bagaimanakah 
ekranisasi pada alur cerita dari novel《金陵十三钗》(Jinnling shisān chäi) karya 严歌苓 (Yan Ge Ling) digambarkan ke dalam film The Flower of War yang ditinjau melalui pendekatan alih wahana.

\section{B. Pembahasan}

\section{Alih Wahana}

Alih wahana merupakan pengubahan dari satu jenis kesenian ke jenis kesenian lain. Alih wahana mencakup kegiatan penerjemahan, penyaduran, dan pemindahan dari satu jenis kesenian ke jenis kesenian lain. Wahana berarti kenderaan, jadi alih wahana adalah proses pengalihan dari satu 'kendaraan' ke jenis 'kendaraan' lain. Sebagai ‘kendaraan' suatu karya seni merupakan alat yang dapat mengalihkan sesuatu dari satu tempat ke tempat lain. Wahana diartikan juga sebagai medium yang dipergunakan untuk mengungkapkan, mencapai, atau memamerkan gagasan atau perasaan. Jadi, pada intinya pengertian itu adalah pemindahan dan pengubahan. Dalam arti yang lebih luas, istilah ini juga mencakup pengubahan dari berbagai jenis ilmu pengetahuan menjadi karya seni (Damono, 2012: 1).

Beberapa istilah yang biasa dikenal dalam kaitannya dengan kegiatan atau hasil alih wahana, antara lain: ekranisasi, musikalisasi, dramatisasi, dan novelisasi. Ekranisasi berasal dari Bahasa prancis écran yang berarti layar, jadi istilah ini mengacu ke alih wahana dari suatu benda seni (pada umumnya sastra) ke film. Musikalisasi umumnya mencakup pengalihan puisi menjadi musik; dramatisasi adalah pengubahan dari karya seni menjadi drama; novelisasi adalah kegiatan mengubah film menjadi novel (Damono, 2012: 4).

\section{Ekranisasi}

Secara etimologis, ekranisasi berasal dari Bahasa Prancis yaitu écran yang berarti layar. Ekranisasi adalah suatu proses pelayarputihan atau pemindahan atau pengangkatan sebuah novel ke dalam film. Pemindahan dari novel ke layar putih mau tidak mau mengakibatkan timbulnya berbagai perubahan terhadap alur cerita, penokohan, latar dan suasana. Oleh karena itu, ekranisasi dapat dikatakan sebagai proses perubahan yang dapat mengalami penciutan, penambahan (perluasan), dan perubahan dengan sejumlah variasi.

Penciutan dalam konteks ini berarti tidak semua hal yang dijumpai dalam novel akan dijumpai pula dalam film, sebagian cerita, alur, tokoh-tokoh, latar, ataupun suasana novel tidak akan ditemui dalam film, sedangkan penambahan dalam konteks ini berarti penambahan pada cerita, alur, penokohan, latar, atau suasana pada film yang dilakukan oleh sutradara film dengan alasan tertentu. Selain penciutan dan penambahan ekranisasi juga memungkinkan terjadinya variasi-variasi 
tertentu antara novel dan film, pada umumnya variasi terjadi karena pembuat film merasa variasi ini dibutuhkan dalam film sehingga memberi kesan film yang didasarkan atas novel tersebut tidak seasli novelnya (Eneste, 1991:60-67).

\section{Teori Alur}

Alur merupakan rangkaian peristiwa-peristiwa dalam sebuah cerita. Istilah alur pada umumnya terbatas pada peristiwa-peristiwa yang terhubung secara kausal, peristiwa kausal merupakan peristiwa yang menjadi dampak dari berbagai peristiwa lain dan tidak dapat diabaikan karena akan berpengaruh pada keseluruhan karya, oleh karena itu dapat dikatakan alur merupakan tulang punggung cerita (Stanton, 2007: 26-28).

Stanton membagi alur ke dalam ada tujuh tahap, yaitu sebagai berikut:

(1) Eksposisi (Exposition) merupakan tahap awal cerita, pada tahap ini pengarang memperkenalkan tempat kejadian, waktu, topik dan tokoh.

(2) Rangsangan (Inciting Moment) pemunculan masalah yang ditampilkan oleh pengarang untuk dikembangkan.

(3) Penggawatan (Rising Action) penanjakan konflik yang selanjutnya terus terjadi peningkatan konfilk.

(4) Perumitan (Complication) adalah konfilk yang semakin sulit, peristiwa dramatic yang menjadi inti cerita semakin menegangkan. Konflik internal, eksternal ataupun keduanya, pertentangan, benturan antar kepentingan dan tokoh yang mengarah ke klimaks semakin tak terhindari.

(5) Klimaks (Climax) merupakan hal terpenting dalam suatu plot, klimaks terjadi karena adanya konflik. Klimaks sangat menentukan bagaimana konflik akan diselesaikan, dapat dikatakan bahwa nasib tokoh utama cerita ditentukan di bagian ini.

(6) Peleraian (Falling Action) bagian ini menampilkan tahap tertentu sebagai akibat dari Klimaks. Jadi, pada bagian ini berisi bagaimana akhir sebuah cerita.

(7) Penyelesaian (Denouement) Konflik yang mencapai klimaks diberi penyelesaian, ketegangan dikendorkan. Konflik-konflik yang lain, sub-subkonflik atau konfil tambahan jika ada juga diberi jalan keluar, cerita diakhiri.

Penyelesaian cerita dapat dikategorikan menjadi dua golongan, yaitu sebagai berikut:

1 Penyelesaian tertutup 
Keadaan akhir sebuah karya fiksi memang sudah selesai sesuai dengan tuntutan logika yang dikembangkan. Penyelesaian ditentukan dengan pasti oleh pengarang dan diterima apa adanya oleh pembaca.

2 Penyelesaian terbuka

Keadaan akhir sebuah karya fiksi yang sebenarnya masih belum berakhir, berdasar tuntutan dan logika karya fiksi tersebut masih memiliki potensial untuk dilanjutkan. Pengarang memberi kesempatan pada pembaca untuk ikut memikirkan, mengimajinasikan, dan mengkreasikan bagaimana kira-kira penyelesaian. Pembaca bebas untuk mengkreasikan penyelesaian cerita sesuai dengan harapannya.

Pada prinsipnya alur dapat dibagi menjadi tiga bagian, yakni:

1) Alur Awal yang terdiri atas Eksposisi (Exposition), Rangsangan (Inciting Moment), dan Penggawatan (Rising Action).

2) Alur Tengah yang terdiri atas Perumitan (Complication) dan Klimaks (Climax).

3) Alur Akhir yang terdiri atas Peleraian (Falling Action) dan Penyelesaian (Denouement).

Berdasarkan urutan kronologis alur dapat dibagi menjadi tiga tahap, yaitu sebagai berikut:

1) Alur maju disebut juga dengan alur linear, penulis menyajikan jalan ceritanya secara berurutan dimuali dari tahapan perkenalan ke tahapan penyelesaian secara urut dan tidak diacak.

2) Alur mundur disebut juga dengan alur flash back, penulis memulai ceritanya dari konflik menuju penyelesaian kemudian menceritakan kembali latar belakang timbulnya konflik tersebut.

3) Alur campuran disebut juga dengan alur maju-mundur, cerita diawali dengan peristiwa yang terjadi pada masa kini kemudian tedapat kilas balik (masa lampau) lalu kembali menceritakan peristiwa yang terjadi masa kini.

\section{Hasil Penelitian}

\section{Penggambaran Alur pada Novel Jīnlíng Shísān Chāi 《金陵十三钗》karya Yang Ge Ling}

Pada umumnya Alur pada novel dapat dibagi menjadi beberapa tahapan yaitu: Eksposisi (Exposition), Rangsangan (Inciting Moment), Penggawatan (Rising Action), Perumitan (Complication), Klimaks (Climax), Peleraian (Falling Action) dan Penyelesaian (Denouement). 
Jika ditinjau dari segi penyusunan peristiwa atau bagian-bagian yang membentuknya, dikenal adanya alur linear, dan alur flash back atau sorot-balik. Dalam alur linear, cerita dimulai dari eksposisi, melampaui komplikasi dan klimaks yang berawal dari konflik tertentu, dan berakhir pada penyelesaian atau denoument. Sebaliknya, dalam plot regresif, awal cerita bisa saja merupakan akhir, demikian seterusnya: tengah dapat merupakan akhir dan akhir dapat merupakan awal atau tengah. Pada bagian ini akan diuraikan tahapan-tahapan alur yang terdapat pada novel

\section{《金陵十三钗》(Jīnlíng shisān chāi).}

\section{a. Eksposisi (Exposition)}

Eksposisi merupakan tahap awal dimulainya suatu cerita, pada tahap ini pengarang memperkenalkan tempat kejadian, waktu, topik dan tokoh. Berikut kutipan novel 《金陵十三钗》 (Jīnlíng shísān chāi) yang memperlihatkan tahap awal cerita.

“我的姨妈孟书娟一直在找一个人。准确地说, 在找一个女人。找着找着, 她渐渐老了, 婚嫁大事都让她找忘了。等我长到可以做她谈手的年龄, 我发现姨妈找了一辈子的女 人是个妓女。在她和我姨妈相识的时候, 她是那一行的花鬼。用新世纪的语言, 就是 腕级人物。”(金陵十三钗, 2012:1)

"Tante saya Meng Shu Juan terus mencari seseorang, lebih tepatnya seorang wanita. Dia sangat tekun mencarinya tanpa disadari usianya sudah tua, bahkan dia tidak lagi memikirkan pernikahan. Ketika saya sudah memasuki umur yang dapat menjadi teman bicaranya, saya baru mengetahui bahwa wanita yang selama ini dia cari adalah seorang wanita penghibur. Pertama kali tante saya berkenalan dengan wanita ini, pada saat itu wanita ini merupakan wanita nomor satu di bidangnya. Apabila menggunakan bahasa jaman sekarang, dapat dikatakan wanita ini merupakan orang terkenal."

Berdasarkan kutipan diatas dapat diketahui bahwa topik dan tokoh utama dalam novel adalah Meng Shu Juan. Pada narasi ini, tokoh Meng Shu Juan digambarkan sedang mencari seorang wanita. Kemudian pada kutipan selanjutnya dipaparkan waktu dan tempat kejadian dimana Shu Juan sempat melihat wanita itu sebagai berikut:

“一九四六年八月，在南京举行的对日本战犯的审判大会上，我老姨几乎找到了她。

她坐在证人席上，指认日军高层军官的一次有预谋的大规模的强奸。”（金陵十三钗， 2012:1) 
Tahun 1946, diadakan pengadilan bagi para kriminal perang, tante saya hampir ketemu dengan dia. Dia duduk di tempat saksi, dan bersaksi atas kejahatan pemerkosaan besar-besaran yang direncanakan oleh petinggi militer jepang.

Selanjutnya melalui kutipan dibawah dapat diketahui nama wanita ini dan alasan mengapa Meng Shu Juan ingin mencarinya.

“赵玉墨!”届时只有二十岁的孟书娟小声惊唿。叫赵玉墨的女人禬着两只装煳涂的眼 睛。“我是孟书娟啊! ”我姨妈说。她摇摇头, 用典型的赵玉墨嗓音说: “你认错人 了。”三十年代南京的浪子们都认识赵玉墨, 都爱听她有点跑调的歌声。我的书娟姨妈 不屈不挠, 挤到她侧面, 告诉她, 孟书娟就是被赵玉墨和她的姐妹们救下来的女学生 之一啊!”(金陵十三钗，2012:2)

"Zhao Yu Mo!" sesaat hanya suara kecil Shu Juan yang berumur dua puluh tahun memanggil. Wanita yang dipanggil Zhao Yu Mo memasang tatapan pura-pura bingung. " saya Meng Shu Juan!" ucap tante saya. Dia menggelengkan kepala, sambil berkata dengan nada bicara khas Zhao Yu Mo "anda salah mengenal orang". Tante saya tidak menyerah begitu saja, dia berdesak-desakan sampai ke samping Zhao Yu Mo dan memberitahu dia bahwa Meng Shu Juan adalah salah satu siswi yang diselamatkan Zhao Yu Mo dan para saudarinya!"

Kemudian pada kutipan berikut dapat dilihat permulaan dari tragedi yang menimpa Shu Juan dan kawan-kawannya ketika Jepang menginvasi Nanking

“她搜集的资料浩瀚无垠。在这个资料展示的广漠版图上，孟书娟看到了1937 年12月 13 日南京亡城时自身的坐标, 以及她和同学们藏身的威尔逊福音堂的位置。资料给她 展示了南京失陷前的大画面，以及大画面里那个惊慌失措的、渺小如昆虫的生命这就 是我十三岁的姨妈，孟书娟。”(金陵十三钗，2012:3)

Melalui data-data yang dia kumpul, Meng Shu Juan dapat melihat keadaan kota Nanking yang telah gugur pada tanggal 13 bulan 12 tahun 1937, dan dirinya bersama dengan para temantemannya yang bersembunyi di katerdal Wilson. Data yang telah terkumpul memperlihatkan gambaran besar kota Nanking yang gugur serta nyawa kecil yang berada didalamnya inilah tante saya yang berusia 13 tahun, Meng Shu Juan."

\section{b. Rangsangan (Inciting Moment)}


Pada subbab ini akan dibahas mengenai Rangsangan atau Inciting Moment yang terdapat pada novel 《金陵十三钗》 (Jìnlíng shísān chāi) dimana akan muncul permasalahan yang akan dikembangkan pada tahapan alur berikutnya. Kehadiran permasalahan pada tahap awal dalam novel ini dimulai dari narasi tentang hilangnya kesempatan para siswi katerdal Wilson untuk mengungsi dari kota Nanking saat Jepang menginvasi terlihat dari kutipan berikut.

“坚守军或许出于内疚，疯了一样为吃了他们子弹的伤号在江边抢船。神父和女学生们 就这样失去了他们的轮渡。”(金陵十三钗，2012:5)

Pasukan penjaga merasa bersalah setelah menembaki teman mereka sendiri, mereka seperti orang gila merebut kapal yang berada di tepian sungai untuk korban peluru yang ditembaki mereka. Begitulah pendeta dan para siswi kehilangan kapal mereka.”

Permasalahan selanjutnya tampak pada narasi yang mengisahkan tentang kedatangan para wanita penghibur dari distrik Qin Huai yang meminta perlindungan dari Katerdal Wilson sebagai berikut:

“趁这个空当, 墙头上的女人们都像雨前田鸡一样纷纷起跳, 落进院内。还剩一个黑皮 粗壮的女人，从墙外又拽上三四个形色各异、神色相仿的年轻窑姐。”(金陵十三钗， 2012:5)

Dengan memanfaatkan kesempatan ini, para wanita yang berada di atas tembok satu persatu melompat turun ke halaman. Masih tersisa seorang wanita gemuk berkulit hitam diatas tembok yang sedang menarik tiga atau empat wanita penghibur mudan yang memiliki postur tubuh berbeda namun ekspresi merekasama.

Selanjutnya keadaan kota yang semakin memburuk membuat mereka harus tinggal lebih lama di Katerdal Wilson

“中午，去安全区筹粮的法比回到教堂，粮没拉回来，坏消息带回来了。马路上中国人 的户体有三四岁的, 也有七八十岁的，一些女人是赤着下身死的。炸弹在路面上炸出 的坑洼和壕沟，都用尸首去垫平。凡是听不懂日语呵斥的，凡是见了枪就掉头跑的， 当场便撂倒，然后就作为修路材料去填沟坎。”(金陵十三钗，2012:20)

Siang hari, Fabio pulang dari tempat pengungsian bukan membawa makanan tapi kabar buruk. Mayat anak-anak berumur tiga atau empat tahun tergeletak di jalanan ada juga mayat anak- 
anak sekitar umur tujuh atau delapan tahun, beberapa mayat perempuan ditemukan tak berbusana. Lubang dijalan akibat ledakan bom ditutup dengan mayat. Tentara Jepang langsung menembaki orang yang tidak bisa berbahasa jepang maupun yang langsung melarikan diri ketika melihat senapan lalu mayatnya digunakan untuk menutupi lubang di jalan.

Disertai dengan persediaan makanan dan air semakin menipis, dapat terlihat dari kutipan percakapan antara Pendeta Engelmann, George Chen dan Pendeta Fabio berikut ini.

“所以，粮食和水是最致命的问题。因为我们收留了十几位女士。”法比说。

“乔治，”英格曼开口问道，“我们还有多少粮食？”

陈乔治说: “还有一担面粉, 米只有一升不到。水就是洗礼池那一点......恩, 不过还有 两桶酒。”法比膯了陈乔治一眼, 难道酒可以洗脸洗澡洗衣? 难道酒能泡茶, 能当水 煮饭下面？尽讲些不相干的屁话！二十岁的陈乔治也委屈地回敬法比一眼，水少了大 人你可以多喝点酒，反正你喝酒跟喝水似的。 英格曼神父居然说: “比我想象得好。”

“一担面粉这么多人? 两天就喝西北风去! ”法比发着小脾气对陈乔治说，怎么办呢? 他又不能对神父发脾气，把该神父听的恼火语言让陈乔治受去，所有人受不了的气都 会让二十岁的孤儿陈乔治受。”(金陵十三钗，2012:21-22)

"Oleh karena itu, makanan dan air adalah masalah terpenting, karena kita menampung puluhan lebih perempuan.” Ucap Fabio

“George" Pendeta Engelmann pun bertanya, "kita masih ada berapa banyak makanan?"

George menjawab "masih ada satu dan $(1 \mathrm{dan}=50 \mathrm{KG})$ tepung terigu, beras tidak sampai satu sheng $(1$ sheng $=1$ liter $)$, dan masih ada sedikit air yang tersisa di kolam pembaptisan, tapi kita masih ada dua tong arak." Fabio menatap George Chen, memangnya arak bisa digunakan untuk cuci muka, mandi dan cuci baju? Memangnya bisa digunakan untuk membuat teh dan menanak nasi? Entah omong kosong apa yang dikatakan kamu! George Chen dengan kesal membalas tatapan Fabio, kalau air tinggal sedikit sebagai gantinya kan bisa minum arak, lagipula bagi kamu minum arak dan air sama saja.

Pendeta Engelmann berkata " lebih baik dari perkiraan saya"

"satu dan $(1$ dan $=50 \mathrm{KG})$ tepung terigu untuk orang sebanyak ini? Dua hari kita sudah tak bersisa !" ujar Fabio yang sedikit emosi terhadap George Chen, mau bagaimana lagi? Dia tidak 
Vol.1, No.1, April 2017, PP. 40-74

bisa mengamuk pada pendeta Engelmann, akhirnya dia melampiaskan amarahnya ke George Chen yang seorang yatim piatu berusia dua puluh tahun.

Kemudian terjadi konflik antara para siswi dengan wanita penghibur yang kedapatan mengambil jatah roti mereka

“陈乔治，你怎么把我们的饼干给她们吃？”书娟问道。

“她们”二字不是说出来 的, 是骂出来的。

陈乔治说: “她们来要的! ”

“要你就给啊？”苏菲说。苏菲是孤儿，所以教会学校老师给她个洋名字“苏菲”她只 能认下来。

“艾哟，还护食呢？”黑皮窑姐笑道。

“先借你们点吃吃，明天馄饨担子就挑出来了，买三鲜馄饨还你们，啊？”红菱说。

“陈乔治，你袭啦？”书娟大声说。(金陵十三钗，2012:23)

“George Chen, mengapa kau mengambil roti kami untuk mereka?” Tanya Shu Juan dengan nada marah.

"Mereka datang meminta" jawab George Chen

"Mereka minta langsung kamu kasih?" tanya Sophie. Sophie anak yatim piatu, maka guru di gereja memberikan nama barat kepada dia "Sophie".

“Aiyo, masih tidak mau berbagi makanan?" ujar wanita penghibur berkulit hitam sambil tertawa.

"Pinjam dulu makanan kalian, sebagai gantinya nanti saya belikan pangsit ya? Ujar Hong Ling.

“George Chen, kamu sudah tuli?” ujar Shu Juan suaranya membesar.

Kemudian konflik yang terjadi antara siswi dengan wanita penghibur bernama Hong Ling lebih diperlihatkan lagi pada kutipan berikut

“你们拿五个子玩不起来, 我们缺五张牌也玩不起来。”红菱跟女孩们拉扯起生意来

了。女孩们你看看我我看看你。有一个胆大的学她的江北话: “......也玩不起来......”. 声哄笑。

法比呵斥她们: “谁拿了她的东西, 还给她! ” 
女孩们七嘴八舌: “哪个要她的东西？还怕生大疮害脏病呢！”

红菱给这话气着了，对她们喊：“对了，姑娘我一身的杨梅大疮，脓水都流到那些骨牌 上, 哪个偷我的牌就过给哪个! ”女孩们发出一声作呕的呻吟。有两个从窗口吐出唾

沫来，是猫准红菱吐的，但没有中靶。“(金陵十三钗，2012:28-29)

"kalian cuma ambil lima biji juga tidak bisa main, kami juga tidak bisa main karena kurang lima biji。" Hong Ling mulai berunding dengan para siswi. Para siswi melihat satu sama lain. Lalu ada seorang siswi yang meniru dialek Jiang Bei Hong Ling: “...juga tidak bisa main...” seakan-akan meledek Hong Ling.

Fabio menegur mereka: "siapa yang mengambil barangnya, cepat kembalikan!"

Para Siswi mengomel: "siapa yang mau ambil barangnya? Kami tak mau terkena penyakit kelamin!"

Hong Ling emosi mendengar perkataan ini, dia meneriaki para siswi : "benar juga, seluruh tubuhku penuh dengan penyakit ini, yang mengambil biji mahjong saya bakalan ketular penyakit ini!”。Para Siswi membuat suara seakan-akan mereka merasa jijik. Dua orang siswi membuang ludah ke arah Hong Ling, tetapi tak mengenai sasaran.

Dari kutipan diatas aksi para siswi menyembunyikan biji Mah Jong milik Hong Ling adalah bentuk pembalasan atas perlakuan Hong Ling yang mengambil roti mereka sesuka hati.

\section{b. Penggawatan (Rising Action)}

Pada subbab ini akan dibahas mengenai penggawatan atau rising action yang merupakan bagian dimana suatu konflik ditanjakan lagi sampai terjadi peningkatan konflik, pada bagian ini sebuah konflik akan semakin terlihat, dalam Novel 《金陵十三钗》 (Jīnlíng shísān chāi) penggawatan atau rising action dimulai dari pertengkaran antara para siswi dengan seorang wanita penghibur bernama Dou Kou yang terdapat pada data kutipan berikut

“晚餐时豆冦走进餐厅。她自己也知道自己不好, 很不识相, 绣花鞋底蹭着老旧的木板 地面，讪讪地笑道: “有汤呢! ”(金陵十三钗，2012:55)

Ketika waktu makan malam Dou Kou masuk ke Kantin. Dia tahu dia tak seharusnya melakukan itu, benar-benar tak tahu diri, sambil menggesekan dasar kaus kaki bermotifnya ke lantai kayu, dia tertawa malu : " ada sup ya !" 
Dari kutipan diatas terlihat Dou Kou bermaksud meminta sup dari para siswi, namun para siswi tidak mau berbagi dan malah mengejeknya seperti yang terlihat pada kutipan berikut

“但豆冦刚往门口走，又有人说: “六月的烂冬瓜”。说这话的人是徐小愚。 “烂得籽啊襄啊都臭了。”苏菲说。豆冦回过身, 猝不及防地把碗里的汤朝苏菲泼 去。豆冦原本不比这些女孩大多少, 不通书理, 心智更幼稚几分, 只是身体成熟罢 了。女孩们憋了满心焦虑烦闷悲伤，此刻可是找到发泄出口，顿时朝豆冦扑过” (金陵 十三钗，2012:56-57)

Ketika Dou Kou berjalan menuju pintu, lagi-lagi seseorang mengatakan : “dasar buah kundur busuk". Yang mengatakan ini adalah Xu Xiao Yu. "busuk sampai ke biji dan bulir"kata Sophie. Dou Kou berbalik badan, dan langsung meyiram Sophie dengan sup yang berada di mangkok. Usia Dou Kou tidak jauh berbeda dari para siswi, karena tak terpelajar sifatnya masih kekanak-kanakan, cuma tubuhnya terlihat dewasa. Segala kecemasan, keresahan dan kesedihan di dalam hati para siswi, saat ini juga menemukan tempat pelampiasan, mereka langsung menuju kearah Dou Kou.

Pada kutipan selanjutnya dapat dilihat Dou Kou dikeroyok oleh para siswi “....门打开时, 豆冦满脸是血, 头发被揪掉一撮。她手正摸着头上那铜板大的秃疤, 把 烛光反射在上面。陈乔治赶紧过去, 想把豆冦从地上扶起来。她手一推, 自己爬了起 来, 嘴还硬得很: “老娘我从小挨打, 鸡毛掸子在我身上断了几根, 怕你们那些嫩拳头? 十几个打我一个，什么东西! ”(金陵十三钗，2012: 57)

“...begitu pintu terbuka, muka Dou Kou berlumuran darah, rambutnya dijambak hingga rontok segengam. Tangannya sedang meraba bagian kepalanya yang botak, George Chen segera menuju ke arah Dou Kou untuk membantu dia berdiri. Namun dia tidak mau dibantu, dia berdiri sendiri sambil marah-marah : “dari kecil saya sudah sering dipukul ibu saya, entah sudah berapa banyak kemoceng yang patah di badan aku, kalian pikir aku takut dengan pukulan kalian? puluhan orang memukuli Satu orang, apa-apaan!

Malam harinya Katerdal Wilson didatangi oleh dua orang tentara China yang berhasil melarikan diri dari lapangan eksekusi, mereka meminta perlidungan di dalam Katerdal Wilson 
Vol.1, No.1, April 2017, PP. 40-74

ISSN: 2579-4906

“隐约听到门口响起门铃声。所有女孩在三秒钟之内坐起，然后陆续挤到窗口。他们看 见阿顾和法比从她们窗下跑过去。阿顾拎着个灯笼先一步来到门前, 法比追上去, 朝 阿顾打着猛烈的手势, 要他熄灭灯笼, 但是已经太晚了, 灯笼的光比人更早到达, 并 顺着门缝到达了门外。

“求求大人，开开门，是埋尸队的……这个这个当兵的还活着，大人不开恩救他，他 还要给鬼子枪毕一次! .......” ”(金陵十三钗，2012: 68)

"bunyi bel pintu gerbang terdengar samar-samar. Dalam waktu tiga detik para siswi terbangun lalu mereka saling berdesakan di jendela. Mereka meilhat Ah Gu dan Fabio berlari keluar. Sambil membawa lampu teplok Ah Gu berdiri di depan pintu, Fabio menyusul Ah Gu, dia mengisyaratkan $\mathrm{Ah} \mathrm{Gu}$ untuk memadamkan lampu, tapi sudah terlambat cahaya lampu telah terlihat dari balik celah pintu .

"Tolonglah tuan, tolong buka pintu, saya tukang kubur...tentara ini masih hidup, apabila tuan tidak membantunya, dia bisa dieksekusi tentara Jepang sekali lagi!...”

Pendeta Engelmann segera menyusul, namun dia menolak membukakan pintu gerbang untuk kedua orang tentara China ini karena dia merasa kesal dibohongi oleh mereka, saat itu juga mayor Dai muncul dan mencegat Pendeta Engelmann.

\section{c. Perumitan (Complication)}

Pada Subab ini akan dibahas mengenai Perumitan atau Complication yang merupakan bagian dimana suatu konflik dalam cerita dipersulit, peristiwa dramatis yang menjadi inti cerita semakin menegangkan. Konflik internal, eksternal, pertentangan, benturan antar kepentingan dan tokoh yang mengarah ke klimaks semakin tak terhindari. Perumitan yang terdapat dalam Novel 《金陵 十三钗》(Jīnlíng shisāan chāi) dimulai dari kedatangan sekelompok Tentara Jepang ke Katerdal Wilson, mereka bersikeras masuk dengan alasan meminta makanan

“我们饿!”带头的日本下等军官用滑稽的英文说道。

“我们也饿。”英格曼说。以怜惜普天下所有的喊饿的生命的那种泛意关怀: “并且干 渴。”他补充道。

“我们要进去。”下等日军军官说。 
“对不起，这是美国教堂。阁下应该把它当美国国土对待。”英格曼坚决不收起笑

容。

“美国大使馆我们都进。”“(金陵十三钗，2012: 137-138)

"kami lapar!” kata Tentara Jepang pangkat rendah dengan Bahasa inggris yang aneh.

“Kami juga lapar.” Kata Pendeta Engelmann “dan haus” tambah dia.

"Kami mau masuk." kata Tentara Jepang berpangkat rendah itu.

"Maaf, ini adalah Katerdal Amerika, tuan seharusnya melihat dan memperlakukan tempat ini sebagai tanah amerika." Kata Pendeta Engelmann sambil tersenyum

"Kedutaan besar amerika serikat saja sudah kami masuk."

Pendeta Engelmann terpaksa harus mengorbankan mobil Ford kesayangannya untuk mengalihkan perhatian tentara jepang dari ruang persembunyiaan para siswi

“去叫乔治发动汽车。”

法比领会了神父的意思。日本兵抢到一辆汽车, 就可以在上级那里领赏, 也可以用它 跟汉奸换吃的和易带的值钱物，比如金银珠宝。“(金陵十三钗，2012: 139)

"Suruh Geroge hidupkan mobil"

Fabio mengerti maksud Pendeta Engelmann. Begitu tentara jepang mengambil sebuah mobil, mereka akan mendapat imbalan dari atasannya, atau mereka juga bisa menggunakan mobil ini untuk ditukar dengan makanan atau barang berharga seperti emas, perak dan mutiara.”

Tokoh Pendeta Engelmann berusaha meyakinkan prajurit jepang bahwa mobil Fford ini merupakan satu-satunya benda berharga yang dimiliki Katerdal ini. Dia berharap tentara Jepang tidak akan kembali lagi.

“英格曼神父说: “这不是我的个人财产，是教会财产，本人没有权力借给任何人。”他 亲爱的老福特是他抛出的替死鬼, 必须牺牲它来保住藏在阁楼上和地下仓库里的生 命，尽管他与老福特的关系更亲，更难舍难分。他说了那番话，为了让日本兵相信， 这番割舍对他的迫不得已，除此外教堂再没有值得他们垂青的物事了。他加了一句: “所以能否请长官打一张借条，我好跟教会财务部门交待？”” (金陵十三钗，2012: 140) 
Pendeta Engelmann berkata: "ini bukan harta saya, melainkan milik Katerdal, saya tidak punya kekuasaan untuk meminjamkannya ke siapapun." Mengkambinghitamkan mobil ford kesayangannya adalah idenya sendiri, harus mengorbankan mobil ford demi melindungi nyawa di loteng dan di ruang bawah tanah pikir Pendeta Engelmann, meskipun hubungannya dengan mobil Ford sangat erat dan sangat sulit berpisah dengannya. Dia mengatakan perkataan itu untuk meyakinkan Tentara Jepang bahwa ini adalah satu-satunya benda berharga yang dimiliki Katerdal ini, selain itu tak ada benda berharga lain yang bisa mereka rebut lagi. Dia menambahkan: "jadi bisakah kalian membuat selembar surat pinjam, saya akan meyampaikan hal ini ke bagian keuangan Katerdal Wilson."

Setelah itu Mobil Ford dibawa pergi oleh tentara jepang

“不管英格曼神父和法比怎样继续摆出阻拦和讲理的姿态，日本兵们已将老福特推出了 车库。”(金陵十三钗, 2012: 140-141)

Ttentara Jepang mendorong mobil Ford keluar dari garasi tanpa mempedulikan sikap Pendeta Engelmann dan Fabio yang terus menerus berusaha menghambat mereka dan berusaha menjelaskan sesuatu.

Perumitan selanjutnya terjadi antara Shu Juan dengan $\mathrm{Xu}$ Xiao $\mathrm{Yu}$, hubungan pertemanan mereka berakhir disini, bukan hanya Xiao Yu teman yang lain juga ikut mengucilkan Shu Juan.

\section{d. Klimaks (Climax)}

Pada Subbab ini akan dibahas mengenai Klimaks yang merupakan bagian terpenting dalam suatu alur, pada bagian klimaks sebuah konflik mencapai puncaknya dapat dikatakan bahwa nasib tokoh utama cerita ditentukan pada bagian ini, klimaks pada Novel 《金陵十三钗》(Jinlíng shísān chāi) terlihat pada kutipan berikut ini

“但英格曼神父在推开的门口站住了。

女人们围着大案板，围拢一截快燃尽的蜡烛，好像在开什么秘密会议。

“你怎么在这里？”法比小声问。

“是我叫她们上来的。”玉墨说。

“十几个日本兵刚才没跟他们的长官出去，守在后院墓地里呢！”法比说。 
玉墨接着说: “我们跟日本人走。把学生们留下来。” ”(金陵十三钗, 2012: 220)

"Pendeta Engelmann berdiri sejenak ketika pintu dapur didorong buka para wanita mengelilingi talenan besar dengan lilin yang hampir habis terbakar diatasnya, seperti sedang membuat rapat rahasia.

"Sedang apa kalian disini?” tanya Fabio dengan suara kecil

"Saya yang menyuruh mereka naik." Kata Yu Mo

"Masih ada puluhan tentara Jepang yang tidak keluar bersama dengan atasannya, mereka sedang berjaga di halaman belakang!’ Kata Fabio

Yu Mo menatapnya dengan acuh tak acuh, lalu mengalihkan pandangannya ke Pendeta Engelmann

"Saya sudah berunding dengan para saudari saya..."

Yu Sheng membantah: "kamu berunding dengan siapa?"

Y Mo melanjutkan perkataannya: "kami akan pergi dengan orang Jepang, menggantikan posisi para siswi."

Fabio tidak setuju dengan keputusan Yu Mo, dia merasa kejadian seperti ini tidak seharusnya terjadi maka dia menyalahkan Pendeta Engelmann.

“你们不必顶替女学生。”法比对玉墨说。

玉墨愣了。法比感到英格曼神父的目光刺在他右边的脸刺上。“谁都不去。”

英格曼神父用英文说: “说点有用的话, 法比! ”

“让她们全藏到地下室, 也许日本人搜不出来。”法比说。

“这风险我们骨不起!”

“南京事件的时候, 直鲁军和江右军几次跑进教堂来, 我们不是躲过来了吗? ”法比 启发神父。

“可是日本人已经知道女学生藏在教堂里......”

“那就是你向日本人供认的时候, 已经想好要牺牲这些女人了。”, (金陵十三钗, 2012: 221)

"Kalian tidak usah menggantikan siswi" kata Fabio terhadap Yu Mo 
Yu Mo kebingungan, Fabio merasakan tatapan Pendeta Engelmann di muka bagian kanannya. "siapa pun tidak pergi."

"Fabio ! katakan perkataan yang lebih berguna" sahut Pendeta Engelmann menggunakan Bahasa Inggris

"kita biarkan mereka semua bersembunyi di ruang bawah tanah, tentara Jepang tidak akan menemukan mereka." Kata Fabio

"saya tidak bisa mengambil resiko!"

"ketika kejadian Nanking bukannya kita berhasil sembunyi dari tentara revolusi nasional yang menggrebek Katerdal?" Fabio berusaha meyakinkan Pendeta "tapi orang Jepang sudah tahu siswi masih bersembunyi di dalam Katerdal..."

"itu karena ketika kamu mengakuinya, kamu sudah berencana mengorbankan para wanita ini dari awal."

Namun Yu Mo mengatakan ini bukan kesalahan siapapun, ini adalah keputusan yang dia buat “门铃响了。蜡烛上的火苗扭动一下。 “快到地下室去! ”法比对女人们说: “我活着, 谁也别想拉你们做垫背的! ” “没有拉我们，我们是自愿的。”玉墨看着法比”(金陵十三钗，2012: 222)

Bel pintu berbunyi, api di lilin bergoyang

“cepat ke ruang bawah tanah!” Fabio berkata kepada para wanita:”selagi saya hidup, tidak ada yang memaksa kalian untuk menjadi kambing hitam!"

“tidak ada yang memaksa, kami suka rela.” Kata Yu Mo sambil menatap Fabio."

Yu Mo meminta waktu sekitar dua puluh menit untuk menyamar menjadi siswi

““我去跟少佐说一声，请求他再给我们十分钟。”英格曼说。

“二十分吧。装扮学生, 二十分钟是起码的。”玉墨说。

英格曼神父眼睛一亮, 他没想到赵玉墨的想法比他更聪明、更成熟, 干脆就扮出一批 女学生来!

“你觉得你们能扮得像吗? ”英格曼问。 
Vol.1, No.1, April 2017, PP. 40-74

ISSN: 2579-4906

红菱接着道: “放心吧，神父，除了扮我们自己扮不像，我们扮谁都像！””(金陵十三

钗, 2012: 222)

"Saya meminta waktu tambahan lima belas menit dari ke letnan." Kata pendeta

"Dua puluh menit, untuk menyamar jadi siswi, dua puluh menit paling cepat." Kata Yu Mo

Pendeta Engelmann terkesima, dia tak menyangka pemikiran Zhao Yu Mo lebih cerdas, dan dewasa dengan spontan menyamar menjadi seorang siswi!

"apakah kalian bisa menyamar menjadi siswi?" tanya pendeta Engelmann

Hong Ling menyambung: "tenang saja pendeta, kita bisa menyamar jadi siapapun."

\section{e.Peleraian (Falling Action)}

Pada Subbab ini akan dibahas mengenai Peleraian atau Falling Action yang merupakan tahapan selanjutnya dari klimaks, pada bagian ini akan tampak akhir sebuah cerita. Peleraian dalam Novel 《金陵十三钗》(Jinnling shisān chāi) terlihat dari ketiga kutipan sebagai berikut “二十分钟后, 厨房的门开了, 一群穿黑色水手裙、戴黑礼帽的年轻姑娘走出来, 她们 微垂脸，像恼恨自己的发育的处女那样含着胸，每人的胳膊肘下，夹着一本《圣经》 歌本。”(金陵十三钗，2012: 223)

Dua puluh menit kemudian pintu dapur dibuka, sekelompok nona muda yang mengenakan baju pelaut berwarna hitam dan memakai topi upacara hitam keluar sambil menundukan kepala, masing masing membawa buku lagu alkitab.

\section{f. Penyelesaian (Denouement)}

Penyelesaian atau Denouement merupakan bagian dimana konflik-konflik yang lain, subkonflik atau konflik tambahan juga diberi jalan keluar, cerita diakhiri. Tahap penyelesaian pada Novel 《金陵十三钗》(Jinling shisān chāi) terlihat dari kutipan sebagai berikut “在我二十九岁那年, 我姨妈孟书娟完成了她对十三个秦淮河女人下落的调查。 赵玉墨是十三个女人中唯一活下来的, 也是她证实了那次日本中高层军官如何分享了 她和另外十二个“学生”。其中有两个企图用牛排刀反抗 (从威尔逊教堂餐厅里带走 的牛排刀），但反抗未遂，当场被杀害。其余十一个女人在日本军官享用够了后，又被 发放到刚刚建立的慰安所, 两三年内, 相继死去, 有的是试图逃亡时被击㱔的, 有的是 染病而死, 个别的自杀了。赵玉墨的幸存大概应该归于她出众的相貌和格调, 享受她的 
都是中下层军官，因此对她的把守渐渐放松，使她终于逃跑成功。大概她是在做了四年 慰安妇之后逃出来的, 至于她为什么要整容, 我姨妈一直找不到答案, 我也找不到答 案。”(金陵十三钗, 2012: 228)

"ketika saya berusia dua puluh sembilan tahun, tante saya Meng Shu Juan telah menyelesaikan penelitiannya terhadap nasib tiga belas perempuan dari Sungai Qin Huai. Zhao Yu Mo merupakan satu-satunya yang selamat, Meng Shu Juan juga menemukan apa yang telah dilakukan opsir Jepang terhadap Yu Mo dan dua belas "siswi" lainnya. Dua diantara wanita ini melakukan perlawanan dengan pisau steak yang mereka ambil dari Katerdal Wilson. Akan tetapi, perlawanan mereka sia-sia, mereka terbunuh ditempat. Setelah para siswi ini dilecehkan, mereka dipindahkan ke kamp wanita penghibur tentara yang baru selesai dibangun, dalam dua tiga tahun satu persatu mati, ada yang mati karena mencoba untuk kabur lalu ditembak mati, ada yang mati karena penyakit, ada yang bunuh diri. Zhao Yu Mo bisa selamat mungkin karena penampilan dan wataknya dia mudah mengambil hati orang, saat pengawasan mulai lemah dia mengambil kesempatan ini untuk kabur. Diperkirakan dia kabur setelah empat tahun menjadi wanita penghibur tentara, sampai pada akhirnya mengapa dia mengoperasi wajahnya, tante saya masih belum menemukan jawaban, saya juga tidak menemukan jawaban.”

\section{Penggambaran Alur pada Film The Flower of War}

Pada umumnya jenis dan tahapan alur yang terdapat pada film sama dengan alur yang terdapat pada novel,yaitu : Eksposisi (Exposition), Rangsangan (Inciting Moment), Penggawatan (Rising Action), Perumitan (Complication), Klimaks (Climax), Peleraian (Falling Action) dan Penyelesaian (Denouement). Pada bagian ini akan diuraikan tahapan-tahapan alur yang terdapat pada film The Flower of War.

\section{a. Eksposisi (Exposition)}

Eksposisi dalam film The Flower of War dapat dilihat pada adegan awal dimana sang narator yang merupakan tokoh utama pada film ini yaitu Meng Shu Juan menceritakan ulang keadaan Kota Nanking yang telah jatuh ke tangan Jepang, Meng Shu Juan dan kedua temannya terpisah dari

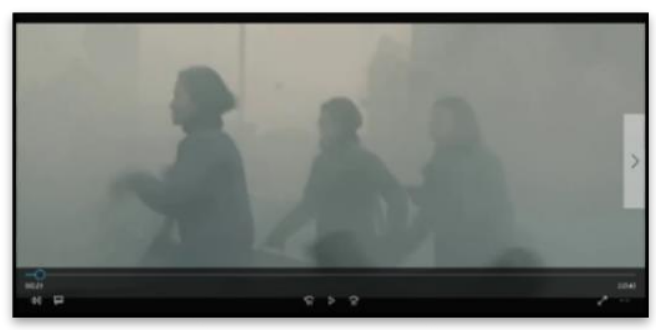


rombongan siswi yang sedang melarikan diri dari kejaran tentara Jepang menuju Katerdal Winchester yang terlihat pada data gambar 1 sebagai berikut:

\section{Shu Juan dan kedua temannya terpisah dari rombongan}

Pada gambar 1, diceritakan bahwa Meng Shu Juan dan seorang temannya memutuskan untuk bersembunyi di sebuah tungku sedangkan teman yang satunya lagi bersembunyi di dalam jerami,

Shu Juan: Let us hide here! (Izinkan kita sembunyi disini!)

Women 1: No more space here, go somewhere else, you can't fit in here !(tidak bisa tempat ini sudah penuh, cepat cari tempat lain, kalian tidak boleh masuk)

Shu Juan:: Let's go (ayo kita pergi !)

(00:03:41-00:03:49)

Beberapa saat kemudian datang tiga orang tentara Jepang mereka mencurigai ada sesuatu dibalik jerami dan menembaknya sehingga teman Shu Juan tewas.

Japanese Soldier 1: Keep Going! (Jalan terus !)

Japanese Soldier 2: Hey you two ! There are people inside!! (Hey kalian! Ada orang di dalam sini!)

Japanese Soldier 3: Who's in there! (Siapa didalam!)

Japanese Soldier 2: Come out! (Keluar!)

Japanese Soldier 1: Come out! (keluar!)

(00:04:03-00:03:49)

Di lain sisi Meng Shu Juan bertemu dengan orang barat bernama Jhon Miller yang kebetulan ingin menuju Katerdal Winchester untuk mengurus pemakaman bagi Bapa Ingelmann.

\section{Tentara Jepang menembaki Jerami}
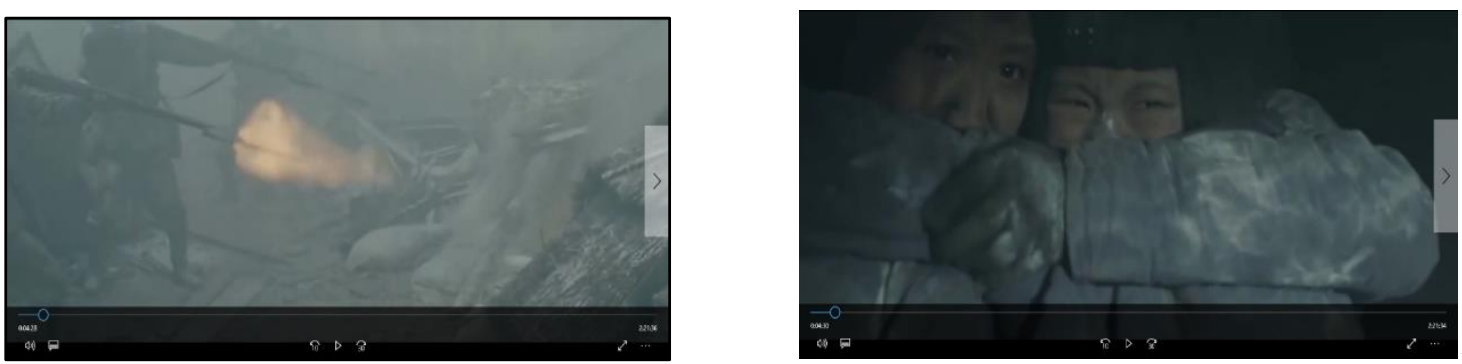

Shu Juan dan temannya bersembunyi ketakutan

Jhon:: Seperated? Seperated from your families? ehm you...families...separated...? I am ...going to... Winchester Cathedral you know where it is? where? (terpisah? Terpisah 
dari keluarga? Ehm... kamu...keluarga...terpisah...?aku...pergi...Katerdal

Winchester...kamu tau dimana?dimana? )

Shu Juan : Mister ... (tuan...)

Jhon: Who said that ? you said mister? you speak English ?(siapa yang bilang itu? Kamu bilang tuan? Kamu bisa berbahasa inggris? )

Shu Juan : We are from Winchester Cathedral (kami dari Katerdal Winchester)

Jhon : you're kidding ? (kamu bercanda?)

Shu Juan: We are student at the convent (kami murid disana)

Jhon: you going there?(kamu mau kesana?)

Shu Juan : why do you want to go there? (kenapa kau mau kesana?)

Jhon: I am helping to bury your father... well not your father father (aku membantu

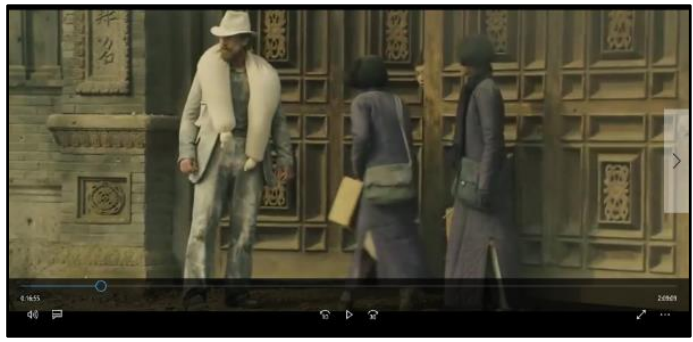

mengubur bapa kalian...bukan bapa sebenarnya)

Shu Juan friend : Father Ingelmann (Bapa Ingelmann)

Jhon: yeah father Ingelman, I'm helping burying him Father Ingelmann I'm helping sending him off to heaven or wherever... you show me the way? (iya Bapa Ingelmann, saya membantu untuk mengantarnya ke surge atau kemana saja...bisa tunjukan aku jalannya?) (00:06:48-00:08:11)

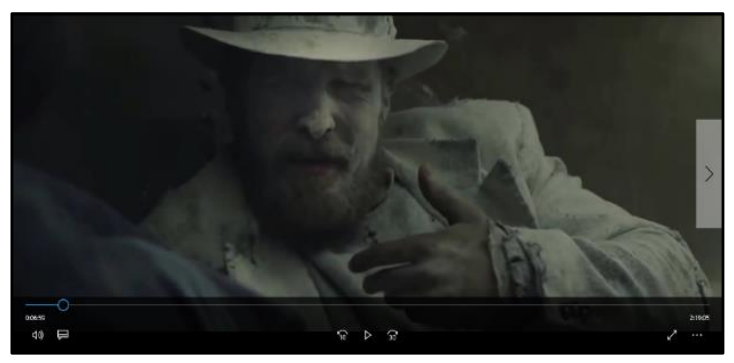

Jhon berbicara kepada siswi

Di lain tempat sekelompok tentara China yang mendapat perintah untuk mundur dari medan perang memutuskan untuk bertahan demi menolong rombongan siswi yang sedang dikejar tentara Jepang, setelah berhasil menolong rombongan siswi para tentara China segera mundur dari posisi 
mereka, namun mereka diserang oleh tentara Jepang dengan mengendarai tank, hanya mayor Li dan seorang tentara kecil bernama Wang Pu Sheng yang selamat dari serangan ini

\section{Mayor Li memikul Wang Pu Sheng}

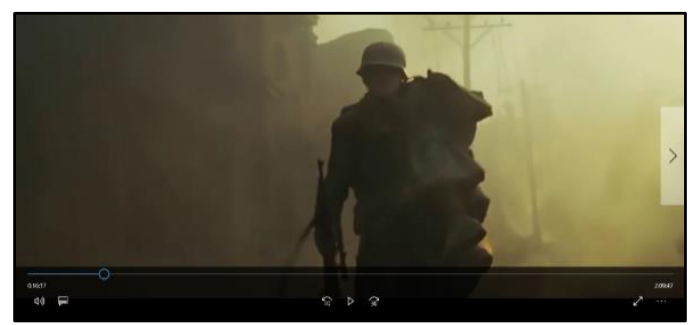

Rombongan siswi akhirnya tiba dengan selamat di Katerdal Winchester, selang beberapa saat Jhon yang mengikuti arah yang ditunjukan Shu Juan dan temannya juga sampai di depan pintu Katerdal Winchester.

\section{Rombongan siswi memasuki Katerdal Winchester.}

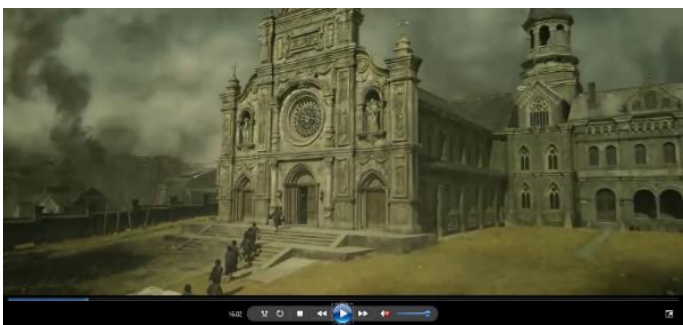

George Chen membuka pintu untuk Jhon dan kedua siswi

\section{Rangsangan (Inciting Moment)}

Rangsangan atau Inciting Moment dalam film The Flower of War dimulai dengan kelakuan Jhon yang egois, meskipun Jhon tidak dapat melakukan pekerjaannya karena jasad Bapa Ingelmann lenyap dia tetap meminta bayaran dari George Chen

George Chen : Father Ingelmann fly away (Bapa Ingelmann terbang)

Jhon : Fly away?(terbang?)

George Chen : On here, Japanese Bomb (disini,bom jepang)

Jhon: He flew away with the bomb right?(jasadnya hilang karena bom ?)

George Chen: Yes (ya)

Jhon : Why was the deceased out here? (kenapa mayatnya diluar?)

George Chen : Gu, all because of Gu...He said bad smell... He move the body here ( Semua karena Gu...dia bilang bau...dia pindah mayatnya ) 
Jhon: Who's Gu? (Siapa Gu?)

George Chen : Gu is our cook...He ran away...He leaves some student here...Some students took away by parents...Some student's nowhere to go (Gu tukang masak kami...dia kabur...meninggalkan beberapa murid disini...beberapa murid dibawa orang tua...beberapa murid tidak bisa kemana-mana)

Jhon : So who is inside...just you and the girls?(jadi siapa didalam...Cuma kamu dan para cewek?)

George Chen: ...(nod his head) (menganggukan kepala)

Jhon:...even without the body you gotta pay me(meskipun jasadnya hilang kamu tetap harus bayar )

George Chen: No (tidak)

Jhon : No No No ... you gotta pay me (tidak...kamu harus bayar saya)

George Chen : No (tidak)

Jhon: That's the rule...There's nothing I can't do about...with what I came through I should raise the price... So is the money inside? (itu peraturannya...saya tidak bisa berbuat apa-apa...belum lagi apa yang telah saya alami seharusnya saya menaikan harganya...jadi uangnya di dalam? )

George Chen : No money ( tidak ada uang )

Jhon : Money?Inside? (uang?di dalam?)

George Chen : No (tidak)

Jhon: Come on, there's no money inside? Let's look...it's catholic church There's gotta be some cash inside (ayolah, tidak ada uang di dalam? Ayo kita lihat...ini gereja katolik pasti ada uang di dalam) (00:17:07-00:18:14)

\section{George Chen menjelaskan keadaan jasad Bapa Ingelmann}


Di lain sisi tampak para siswi sedang berdoa untuk temannya yang tewas, tiba-tiba seorang

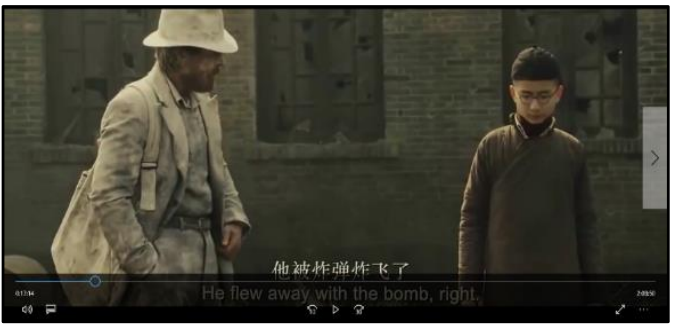

siswi menyalahkan Shu Juan atas semua kejadian yang menimpa mereka, Jhon dan George Chen datang melerai.

Girl Student 1 : It's all your fault, your father promised to take us on a boat and leave Nanking... where is he? He ran off...we wait and wait and now the Japanese are here, they are everywhere and it's too late to go to the refuge...Zhen died because of your father! (semua salahmu, ayahmu janji membawa kita semua keluar dari Nanking...dimana dia?dia kabur...kita tunggu dan tunggu dan sekarang orang jepang sudah dimana-mana dan kita sudah terlambat untuk ke tempat pengungsian...Zhen mati karena ayahmu! )

Shu Juan : Shut up! (diam !)

George Chen : Stop! Stop Fighting ! (berhenti ! jangan bertengkar !)

Jhon : Hey! Hey Stop! ( hei ! hei berhenti !)

$(00: 18: 55-00: 19: 19)$

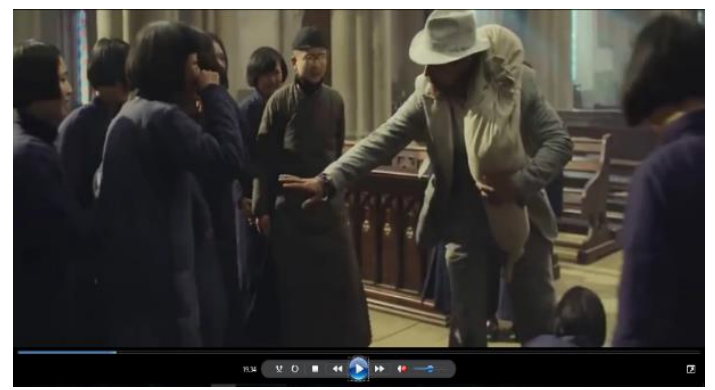

Jhon dan George Chen melerai para siswi

Setelah itu Jhon bermaksud mengambil uang donasi Katerdal, karena tidak bisa menemukan uang di lantai pertama dia mencoba mencarinya di lantai dua, dia menemukan kamar Bapa Ingelmann

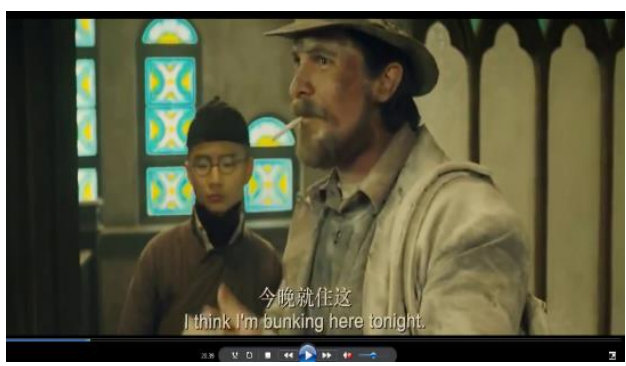


dan memutuskan untuk bermalam disini. George meminta Jhon untuk memperbaiki truk dan membantu mereka untuk keluar dari Nanking tapi Jhon menolak karena George tidak sanggup membayar.

Jhon : Oh nice...Forget going back to refuge, $i$ think i'm bunking here tonight...he is grim, who is that? (Bagus juga...sepertinya saya bermalam disini...tampangnya serius, siapa dia?) George :...

Jhon : is that Father Ingelmann? (Bapa Ingelmann?)

Geroge : yes (Ya)

Jhon : there north european they are all alike...you know tuna, playwrights not much fun...look at that face he is ruining the...what do you call it?feng...feng shui? i can't have a priest staring at me while $i$ am sleeping (Orang eropa utara semua sama...maksud saya tuna, drama...tidak ada yang menyenangkan...lihatlah muka itu, dia menghancurkan...apa yang kau sebut itu? Feng...feng shui ? aku tak bisa membiarkan pendeta menatapku tidur) George: No! my father... me orphan adopted (Jangan ! ayahku...saya yatim piatu diadopsi) Jhon : $i$ am sorry..but $i$ just...it's not good for me to have a priest staring at me while $i$ am sleeping...i can't...please $i$ gotta just..there better...you got any drink around here? (Maafkan aku...tapi...aku tidak bisa ditatap pendeta selagi aku tidur...aku tak bisa...aku hanya... ya lebih baik...ada minuman disini? )

George : No (tidak)

Jhon : you're a church. You got wine, or something ? (kamu gereja, ada anggur atau sejenis? )

George :Nothing! (Semua tidak ada!)

Jhon : Nothing? (Tak ada ?)

George:No..No...No! ( Jangan..Jangan...Jangan!)

Jhon :That's a shaving kit (itu alat cukur)

George : What a jerk ! i said you're a jerk! (benar-benar mengjengkelkan ! aku bilang kamu mengjengkelkan !)

Jhon: What did you say your name was? (Siapa nama kamu lagi ?)

George : George Chen. (George Chen )

Jhon : George (George)

George : tomorrow you fix truck help us .(Besok kamu perbaiki truk bantu kami) 
Vol.1, No.1, April 2017, PP. 40-74

Jhon : Fix truck? ( Perbaiki truk?)

George : No money ( Tidak ada uang )

Jhon :Money. George ( Uang George )

\section{Jhon memasuki kamar Bapa Ingelmann}

Sekelompok wanita penghibur dari Distrik Qin Huai menggedor gerbang Katerdal Winchester sambil meneriakan nama $\mathrm{Ah} \mathrm{Gu}$, mereka datang kesini karena $\mathrm{Ah}$ Gu memberitahu mereka tentara Jepang /tidak berani memasuki bangunan negara asing seperti Katerdal ini. George Chen tidak mengizinkan mereka masuk namun mereka masuk dengan paksa.

\section{b. Penggawatan (Rising Action)}

Penggawatan atau Rising Action dimulai dari sekelompok tentara Jepang yang masuk ke Katerdal Winchester dengan tiba-tiba, sebutir peluru nyasar mengenai seorang siswi hingga tewas ditempat, para siswi dan tiga orang wanita penghibur yang melihat kejadian ini spontan panik. Shu Juan berusaha tenang dan menyuruh George Chen membawa mereka bersembunyi di ruang bawah tanah sementara dia membangunkan siswi yang lain

George Chen : Stop Fighting ! what's going on ? Stop !... What are you doing are you crazy?

We just a kids! (berhenti berkelahi ! apa yang terjadi ? hentikan!...Apa yang kau lakukan kamu gila ? kami cuma anak anak! )

Hong Ling : Hua that's enough! (Cukup Hua !)

Hooker 2 / Hua : No, it's not over! (belum, belum selesai !)

Girl Student 1: I won't let you go in! (tak kubiarkan kau masuk !

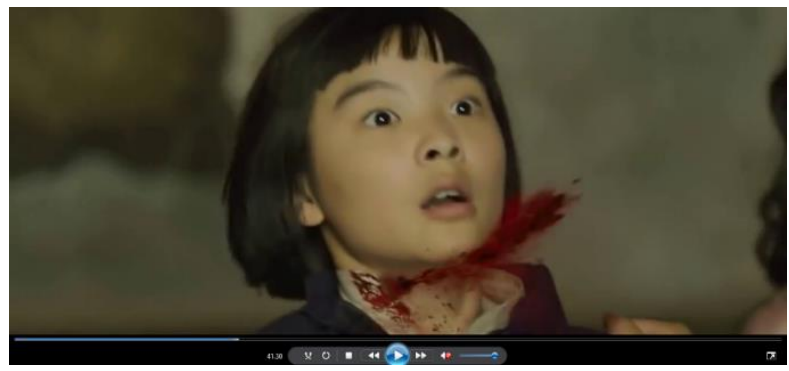

Peluru mengenai leher siswi

Jhon terbangun karena suara tembakan dia melihat gerbang Katerdal Wilson telah dibuka tentara Jepang, Jhon keluar dari kamar tidur dan bermaksud melarikan diri tapi dia tidak tahu harus 
kemana kemudian dia melihat para siswi berlari menuju ruang makan, di lain sisi ketiga wanita penghibur dan George Chen masuk ruang bawah tanah untuk bersembunyi, Hong Ling bermaksud menutup pintu masuk ruang bawah tanah tapi Yu Mo melarangnya karena para siswi belum masuk.

Yu Mo : Come in Hurry! Don't Shut it let the girls in. Let the girls in! (Cepat masuk! Jangan tutup biarkan siswi masuk. Biarkan siswi masuk !)

Shu Juan : Hurry! ( Cepat!)

Japanese Soldier : Don't Move! (Jangan bergerak!) (00:43:02 - 00:43:21)

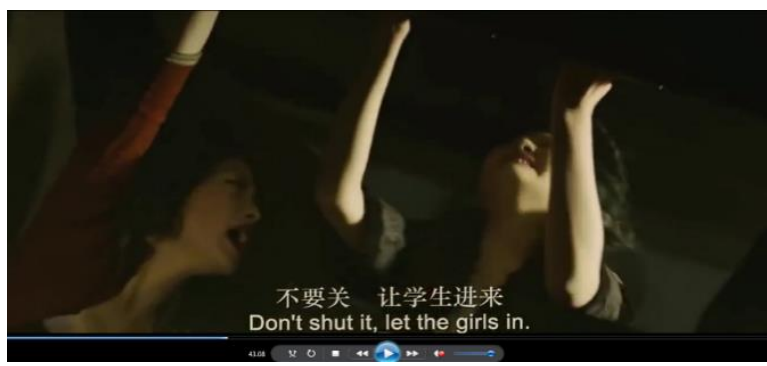

\section{Yu Mo melarang Hong Ling menutup pintu}

Para siswi tidak sempat masuk ke ruang bawah tanah, Shu Juan tidak ingin posisi ruang bawah tanah diketahui tentara Jepang sehingga membahayakan nyawa mereka yang berada di ruang bawah tanah, dia pun menyuruh siswi lainnya ke lantai atas untuk mencari tempat persembunyiaan lain dan mengalihkan perhatian tentara Jepang.

\section{c. Perumitan (Complication)}

Perumitan atau Complication pada film The Flower of War dimulai dari perasaan takut para siswi, karena besok mereka diharuskan menghadiri pesta perayaan tentara Jepang

( Girl students finished singing ) ( Siswi selesai bernyanyi)

Colonel Hasegawa : Good, you sing very well ( Bagus, nyanyiannya bagus)

(Suddenly a hooker named Mosquito come out from behind the stage chasing her kitten, everyone sees her) ( Tiba-tiba wanita penghibur bernama Mosquito keluar dari belakang panggung sambil mengejar kucingnya, semuanya melihat dia )

Shu Juan: What are you doing? Haven't i told you? You can't come out... Officer this student has lost her uniform because we want to look our best today, we ask her not to participate in the performance. Please forgive the intrusion. (Apa yang kamu lakukan? Bukankah sudah kubilang? Kamu tidak boleh keluar...Pak, siswi ini kehilangan seragamnya, karena kami 
ingin tampil sempurna hari ini kami tidak mengizinkannya ikut bernyanyi. Kami mohon maaf atas ketidaknyamanan ini)

Colonel Hasegawa : ... (nod) (mengangguk kepala)

Colonel Hasegawa : Father, $i$ would like to announce some good news tomorrow our division is celebrating the successful occupation of Nanking. Esteemed Father on behalf of all the officers, $i$ would like to invite your church choir to perform and celebrate with us, this is the official invitation (Bapa, saya akan mengumumkan kabar baik besok divisi kami merayakan keberhasilan kami menduduki Nanking. Bapa yang saya hormati, atas nama seluruh perwira, saya ingin mengundang kelompok paduan suara gereja anda untuk bernyanyi dan merayakannya bersama kami, ini undangannya)

Girl Student 5 : They are asking us to sing at the party tomorrow (whisper) ( Mereka meminta kita untuk bernyanyi di pesta besok (berbisik) )

Jhon: This is a very kind invitation Mr Hasegawa. However unfortunately the children will not be able to attend (Ini undangan yang sangat bagus tuan Hasegawa, tapi sayagnya anakanak tidak bisa hadir)

Colonel Hasegawa : Why not?(Mengapa tidak ?)

Jhon: Sir, they are very young i'm not sure that it is appropriate for them to attend an adults party. As their guardian and protector that is my responsibility. But we thank you very mисh.(Tuan, mereka masih muda saya tidak yakin mereka pantas untuk hadir di pesta orang dewasa. Sebagai penjaga mereka itu merupakan tanggung jawab saya. Tapi kami sangat berterima kasih pada anda)

Colonel Hasegawa : I am sorry, this is an order from above i can not disobey.( Maafkan saya, ini perintah dari atas saya tidak bisa melanggar)

Jhon: Sir please think about the girls, $i$ can see that you are a man of culture. Last time you played us a beautiful song for people far from home you missed rivers and hills please consider that theirs have been destroyed, they have no home, nothing. They are living in hell with this invitation you are asking them to celebrate that $i$ know that you understand. With respect sir $i$ cannot allow that $i$ think that is... that is brutal, sir. ( Tuan tolong pikirkan para siswi, saya bisa lihat anda orang yang berbudaya. Waktu itu anda memainkan lagu yang indah bagi orang yang rindu kampung halaman, anda merindukan sungai dan bukit tolong dipertimbangkan kampung halaman mereka telah hancur, mereka tidak punya rumah, tidak 
punya apa-apa. Mereka berada di neraka, dengan undangan ini anda meminta mereka untuk merayakannya saya tahu anda mengerti. Dengan hormat saya tidak bisa mengizinkan itu saya pikir itu...itu brutal, tuan.)

Colonel Hasegawa: Please remember tomorrow at four in the afternoon a car will come to pick up the students. I am carrying out military order. ( Ingat, besok jam empat sore mobil akan menjemput para siswi. Saya melaksanakan perintah militer.)

Jhon: Mr Hasegawa, you tell me what will happen in these celebrations (Tuan Hasegawa, beritahu saya apa yang akan terjadi di perayaan ini)

Colonel Hasegawa : ... (turn his back) (memalingkan badan)

Jhon : Mr Hasegawa...Mr Hasegawa... You said you posted a guards for our security have you been keeping these girls locked up until this celebrations? The children cannot go... Mr Hasegawa...Mr Hasegawa (Tuan Hasegawa...Tuan Hasegawa...Anda bilang anda menaruh penjaga demi keamanan kami, apakah anda cuma memastikan agar para siswi tidak kabur sampai hari H ? Anak-anak tidak boleh pergi... Tuan Hasegawa...Tuan Hasegawa) ( Hasegawa underling holding Jhon ) (Bawahan Hasegawa menahan Jhon) Jhon: The children cannot go ! The children cannot go ! (Anak-anak tidak boleh pergi ! Anak-anak tidak boleh pergi !)

( Hasegawa underling starts counting the girl student) (Bawahan Hasegawa menghitung jumlah siswi)

Hasegawa underling : one, two, three, four, five, six, seven, eight, nine, ten, eleven, twelve ,thirteen...All, must go! ( satu, dua, tiga, empat, lima, enam, tujuh, delapan, sembilan, sepuluh, sebelas, duabelas, tigabelas...Semua, harus pergi !) ( Japanese soldier leaving the catherdal hall) (Tentara Jepang meninggalkan aula Katerdal )

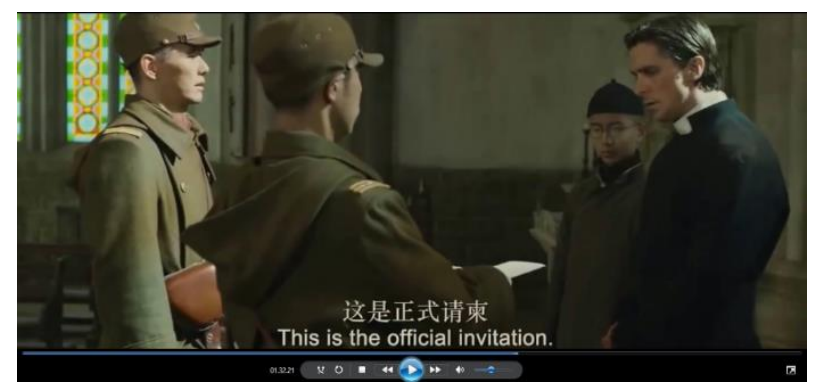

Kolonel Hasegawa menyerahkan undangan 


\section{c. Klimaks (Climax)}

Film The Flower of War sampai ke bagian Klimaks ketika Shu Juan dan siswi lainnya sangat ketakutan, mereka takut akan disiksa oleh tentara Jepang dan akhirnya memutuskan untuk bunuh diri dengan cara meloncat dari menara lonceng Katerdal Winchester. Yu Mo dan para wanita penghibur lainnya berhasil membujuk para siswi turun dengan mengatakan mereka akan menggantikan posisi siswi pergi ke perayaan tentara Jepang.

Girl Student 5 : Shu is there a better solution? (Shu apa tidak ada solusi lain?)

Shu Juan : No. We can't allow the japanese to violate our bodies again.(Tidak, kita tak boleh membiarkan orang Jepang menganiyayai tubuh kita lagi.)

Jhon : Girls ... Shu ! wait just...(anak-anak...Shu ! tunggu...)

Shu Juan : Go away! ( Pergi ! )

Jhon : Calm down ...OK, OK. Stay back, OK ( Tenang...baik,baik, saya mundur, baik) Yu Mo : Don't do anything foolish so many people have died even hell is packed right now why should you add to the crowd? (Jangan melakukan hal bodoh sudah banyak orang mati bahkan neraka sudah penuh, untuk apa berdesakan disana? )

George Chen : Shu don't do this, you can't do this! We can't just throw our lives away. We should receive life with gratitude so our souls can be saved. ( Shu jangan lakukan ini, kamu tak boleh melakukan ini ! Kita tak boleh membuang nyawa kita begitu saja. Kita harus menerima hidup dengan rasa syukur agar jiwa kita bisa selamat)

Shu Juan : Keep away! Step back! (Jangan mendekat ! mundur !)

Jhon: OK, we are stepping back. ( Baik, kita mundur)

Shu Juan : Come up! we have to do this come up! come up! (Cepat naik! kita harus melakukan ini, naik ! Naik !)

Yu Mo: Listen to me Shu, i have an idea, $i$ will go for you. Tell the students to get down, tomorrow $i$ will go for you. Did you hear me? I will go for you! ( Dengarkan aku Shu, aku punya ide, aku akan menggantikan kamu. Suruh siswi lainnya turun, besok aku akan menggantikanmu. Kau dengar? aku akan menggantikanmu !)

Girl Student 3 : What? She will go for you? (Apa? Dia akan menggantikanmu?) Hua : I will also go for you (Aku juga akan menggantikan kamu) 
Hong Ling : Right, we will go for you we can handle the Japs we will protect you, we will go for you. ( Benar, kami akan menggantikan kalian kami bisa menangani orang Jepang kami akan melindungi kalian, kami akan menggantikan kalian.)

Hooker 8 : Don't worry you have us. (Jangan khawatir, ada kami. )

Hooker 9: Yes we won't let the Japanese hurt you. (Betul, kami tak akan membiarkan orang Jepang menyakiti kalian. )

Hooker 1 : Do you hear us? We will go for you, come down and don't jump...come down (Kalian dengar kami? Kami akan menggantikan kalian, turunlah jangan lompat...turun.)

Yu Mo: We are telling them the idea i told you about (Whisper to Jhon) (Kami memberitahu mereka ide yang kubilang kepadamu sebelumnya (Berbisik ke Jhon) )

Jhon : It's a good idea. That's it girls. Shu, come here it's a good idea we can trick the Japanese allright? we'll make it fun. Come down we think about it. We just come down and think about it we can make it work. (Ide bagus. Itu dia. Shu, kemarilah ini ide bagus kita bisa mengelabui orang Jepang ok? Turunlah kita pikirkan ide ini bersama. ) (01:41:08 $01: 43: 23$

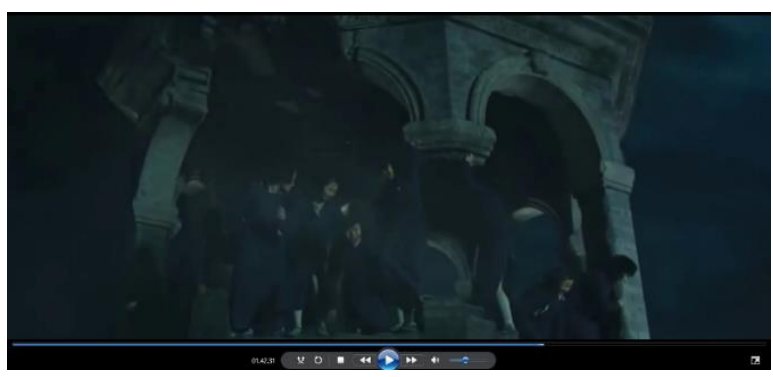

\section{Para siswi nekat mencoba bunuh diri}

Malam itu juga Jhon menggunakan keahliannya untuk merias para wanita penghibur menjadi siswi. Akan tetapi, wanita penghibur ini hanya berjumlah dua belas orang sementara tentara Jepang mengatakan tiga belas siswi harus hadir, melihat hal ini George Chen langsung mengatakan dia akan ikut dengan para wanita penghibur untuk menggantikan para siswi.

\section{d. Peleraian (Falling Action)}

Selanjutnya ditampilkan peleraian atau Falling Action pada film The Flower of War. Jhon mendengar suara tembakan dia melihat kebelakang dan menemukan ayah Shu Juan terbaring dalam keadaan tak bernyawa dengan lubang di kepalanya, Jhon menutupi wajah ayah Shu Juan dengan 
topi sepertinya Jhon ingin melakukan upacara yang layak untuknya. Akan tetapi, hal terpenting yang dilakukan saat ini adalah membawa para siswi keluar dari Nanking. Jhon memanggil para siswi yang telah menyamar menjadi anak laki laki , para siswi membantu Jhon memindahkan kotak anggur ke samping truk, para siswi bersembunyi di dasar bak truk kemudian Jhon menutupi para siswi dengan meja kayu dan memindahkan kotak anggur keatas meja kayu tersebut, setelah mesin truk berhasil dihidupkan Jhon mengendarai truk menuju arah barat dan menemukan sebuah pos perbatasan yang dikawal tentara Jepang. Jhon menunjukan surat izin yang diberi ayah Shu Juan dan memberi tentara Jepang empat kotak anggur akhirnya Jhon diizinkan lewat perbatasan dan meninggalkan kota Nanking.

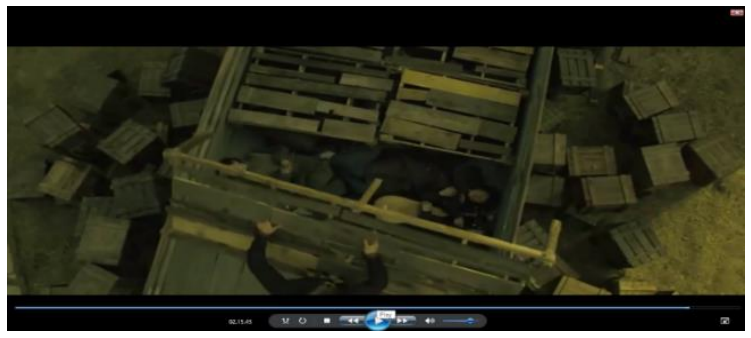

\section{Para siswi bersembunyi di dasar bak truk}

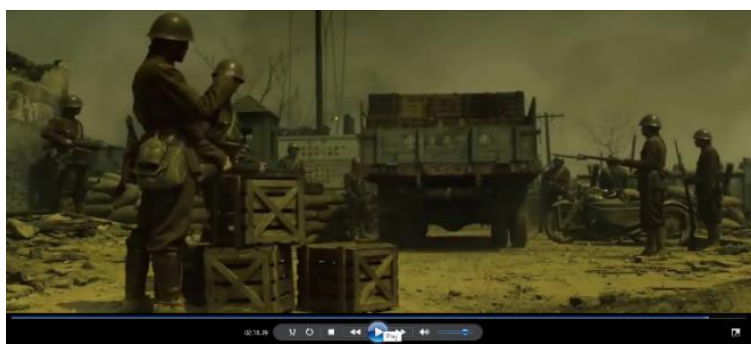

\section{Jhon berhasil melewati perbatasan}

\section{e. Penyelesaian (Denouement)}

Pada bagian penyelesaian atau denouement film The Flower of War Shu Juan mengatakan sampai sekarang dia tidak tahu bagaimana nasib para wanita dari Sungai Qin Huai, dia juga tidak sempat mengetahui nama mereka masing-masing, Shu Juan hanya bisa mengingat ketika para wanita ini berjalan memasuki Katerdal Winchester.

Shu Juan (Monolog) : Until this day i still don't know what happened to the women of the Qin

Huai river. I never learned all of their names and never saw them being taken away by the Japanese. So, $i$ always imagine...i imagine myself standing by the large round window, 
watching them walk in once again. (Sampai sekarang saya belum mengetahui nasib para wanita sungai Qin Huai. Saya belum mengenal nama mereka masing-masing dan tidak melihat bagaimana mereka dibawa pergi tentara Jepang. Jadi, saya selalu membayangkan...saya membayangkan saya berdiri di balik jendela bundar besar sambil melihat mereka berjalan masuk sekali lagi.) (02:19:20 - 02:19:50).

\section{Kesimpulan}

Berdasarkan analisis yang telah dibahas mengenai penggambaran ekranisasi pada alur cerita novel Jīnlíng Shísān Chāi 《金陵十三钗》karya Yán gē líng ke film The Flower of War dapat ditarik kesimpulan bahwa film The Flower of War merupakan produk alih wahana dari novel Jīnlíng Shísān Chāi 《金陵十三钗》 yang sesuai dengan teori ekranisasi mengalami perubahanperubahan baik dari penambahan, pengurangan/penciutan, maupun perubahan bervariasi. Melalui analisis alur cerita dari kedua media dan analisis perubahan alur cerita dari novel ke Film menunjukan bahwa kesamaan paling terlihat dari inti cerita yaitu Pengorbanan yang dilakukan wanita penghibur demi menyelamatkan para siswi dari tentara Jepang yang sedang menginvasi Kota Nanking pada bulan Desember tahun 1937.

\section{DAFTAR PUSTAKA}

Aziez, Furqonul dan Abdul Hasim . 2010 . Menganalisis Fiksi sebuah pengantar .

Bogor: Penerbit Ghalia Indonesia.

Damono, Sapardi Djoko. 2012. Alih Wahana. Jakarta: Editum.

Eneste, Pamusuk. 1991. Novel dan Film. Jakarta: Nusa Indah.

Geling, Yan. 2012. 《金陵十三钗》. 北京: 北京联合出版公司。

Kasim, Razali.1996. Sastra Bandingan ruang lingkup dan metode. Medan: USU PRESS

Nurgiyantoro, Burhan. 2007. Teori Pengkajian Fiksi. Yogyakarta: Gadjah Mada University Press.

Stanton. Robert. 2007. Teori Fiksi. Yogyakarta: Pustaka Pelajar

Thompson, Kristin dan David Bordwell. 2003. Film History: An Introduction $2^{\text {nd }}$ Edition. New York: Mc Graw Hill.

Waluyo, Herman J. 2002. Pengkajian Sastra Rekaan. Salatiga: Widya Sari Press.

Xiang Hong, Li dan Li Qing Yu. 2012. 《中国文学》.上海 : 华东师范大学出版社。 
Xun，Lu.1925.《中国小说的历史的变迁》.西安:西安大学出版社

Qin, Li Yan, 2007. Trans-media strategies of appropriation, narrativization, and visualization: adaptations of literature in a century of Chinese cinema. (http://escholarship.org/uc/item/5vd0s09p) diakses 30 April 2016

Xia, Wang Li, 2015. 《不同版本的话语演变——试论《金陵十三钗》小说与电影的差异》. Jurnal. Shan Dong: Shandong Agriculture and Engineering University.

Yuan, Qian Yuan, 2014. 《从叙事角度看《金陵十三钗》的文本叙事与电影叙事》. Jurnal. Huai Bei: Huaibei Professional and Techincal College

\section{Data Penulis}

$\begin{array}{ll}\text { Nama } & : \text { Intan Erwani, S.S., M.Hum \&Hesti } \\ \text { Program Studi } & : \text { Program Studi S1 Sastra Cina } \\ \text { Perguruan Tinggi } & : \text { FIB Univeritas Sumatera Utara, Medan-Indonesia } \\ \text { Telepon } & :+6281312485066 \\ \text { Email } & : \text { intanerwany@gmail.com }\end{array}$

